\title{
DISPOSITIF DE PRÉLÈVEMENT SANGUIN OBTENU CHEZ LE MOUTON ÉVEILLÉ NON HÉPARINÉ
}

\author{
J. BOST, R. BOIVIN et J.-P. FARGES \\ Chaire de Physiologie, Thérapeutique, Pharmacodynamie, I. N. R. A., \\ École nationale vétérinaire de Lyon, \\ $69-$ Lyon
}

L'utilisation d'un système automatique de prélèvement raccordé à un cathêter ìmplantê dans la veine jugulaire évite de nombreuses causes d'erreurs dans une étude à moyen terme (8 à Io jours) des divers constituants biochimiques du sang.

Une pompe péristaltique assure une aspiration continue dans le cathéter. Le sang peut être dirigé soit vers un dispositif d'analyse automatique, soit vers un collecteur de fractions réfrigéré

Afin d'éviter une héparinisation générale de l'animal qui serait à la fois onéreuse et dangereuse, une solution d'héparine est lentement délivrée par un fin tube de polyéthylène à l'intérieur du cathéter d'aspiration, à $3 \mathrm{~mm}$ de son orifice.

La solution d'héparine ainsi que la solution antiglycolytique placée dans les tubes du collecteur contiennent la même concentration de BSP dont le dosage dans le sang recueilli permet de connaître la dilution de chaque échantillon.

\section{SUMMARY}

\section{BLOOD SAMPLING DEVICE IN CONSCIOUS NON HEPARINIZED SHEEP}

By means of an automatic sampling system connected to a jugular vein catheter, several causes of faults may be avoided during a middle-term study (8-10 days) of the various biochemical blood constituents.

Continuous aspiration in the catheter is produced by a peristaltic pump. The blood may be led either towards an automatic analyzer or towards a refrigerated fraction collector.

In order to avoid a general heparinization of the animal, which would be both onerous and dangerous, a solution of heparine is slowly released through a fine polyethylene tube inside the aspiration catheter, at $3 \mathrm{~mm}$ from the opening of the latter.

The heparine solution as well as the antiglycolytic solution placed in the tubes of the collector have the same concentration of BSP, the determination of which shows the dilution of each sample of blood collected. 